\title{
Changes in cognitive functions in a girl with severe acquired hypothyroidism in comparison to the healthy twin sister
}

\author{
Maia Stanisławska-Kubiak¹, Katarzyna A. Majewska², Andrzej Kędzia², Włodzimierz Samborski³ \\ Marek Ruchała (D) ${ }^{4}$, Ewa H. Mojs ${ }^{5}$ \\ ${ }^{1}$ Department of Clinical Psychology, Poznan University of Medical Sciences, Poznan, Poland \\ ${ }^{2}$ Department of Auxology and Paediatric Nursing, Poznan University of Medical Sciences, Poznan, Poland \\ ${ }^{3}$ Department and Clinic of Rheumatology and Rehabilitation, Poznan University of Medical Sciences, Poznan, Poland \\ ${ }^{4}$ Chair of the Department of Endocrinology, Metabolism, and Internal Medicine, Poznan University of Medical Sciences, Poznan, \\ Poland \\ ${ }^{5}$ Department of Clinical Psychology, Poznan University of Medical Sciences, Poznan, Poland
}

Key words: hypothyroidism; cognitive processes; intelligence; autoimmune hypothyroidism

The main aim of the study was to evaluate the cognitive functions of twin sisters in a situation where one of the girls has been diagnosed with severe hypothyroidism, which (based on the patient's history and growth process assessment) must have lasted for about two years before diagnosis. Over this time, the other sister developed normally and showed no symptoms of thyroid dysfunction, while performed blood tests confirmed euthyroidism. The long time over which hypothyroidism remained undiagnosed in one of the sisters resulted in significant physical (height, motor activity), psychological, and social differences between the girls. The information obtained in the study was used to evaluate the child's condition and determine the difficulties in her functioning, which in turn allowed a better understanding of the girl's needs, and finally to observe the changes occurring as a result of received hormone therapy. In both girls, neuropsychological tests were performed. The following tests were used: Intelligence and Development Scales for Pre-School Children (IDS-P) and neuropsychological tasks for cognitive processes [1]. Test results obtained before the treatment, five months into treatment, and after 15 months of treatment were compared (Tab. 1).

In the first evaluation, the hypothyroid sister scored 92 points on the Fluid Intelligence Scale and 88 points on the Crystallised Intelligence Scale, which leads to the conclusion that the fluid intelligence quotient was significantly higher than the crystallised intelligence quotient. It was possible to reach the conclusion that the child has some specific problems not associated with her general intelligence but rather with a certain disease or disorder. In the first evaluation, the twin sister obtained results that confirmed the normal and harmonious development of specific cognitive functions.

When compared with the general population and the twin sister, the hypothyroid girl scored low in the tests that measured the following: auditory and phonological memory, active and passive speech, persistence, and achievement satisfaction.

Owing to treatment, after five months a significant improvement was observed in the hypothyroid sister with respect to the following: auditory memory, visual-spatial memory, active and passive speech, persistence, and achievement satisfaction. When in treatment, she obtained results that were the norm for her age. What improved was not only visual perception but also selective attention and working memory, as well as cognitive control, allowing her to better concentrate and coordinate all cognitive actions. As far as verbal functions go, her ability to build sentences, use adjectives and adverbs, apply spatial relationships to the story, as well as the fluency of speech and richness of language were also improved.

In the healthy girl, during the first and second evaluation the obtained results were similar and in the norm for her age. After 15 months, the test results for both girls significantly improved. The one receiving treatment obtained results indicating above-average intellectual development and her healthy sister — high intellectual development. 
Table 1. Comparison of test results for twin sisters for given IDS-P sub-tests before and after received treatment - 5 and 15 months into treatment

\begin{tabular}{|c|c|c|c|c|c|c|c|}
\hline & & \multicolumn{3}{|c|}{ Evaluation of hypothyroid child } & \multicolumn{3}{|c|}{ Evaluation of healthy sister } \\
\hline & & First & Second & Third & First & Second & Third \\
\hline \multirow{3}{*}{$\begin{array}{l}\text { Laboratory } \\
\text { parameters }\end{array}$} & $\mathrm{TSH}[\mathrm{mclU} / \mathrm{mL}]$ & $>100.000$ & 0.65 & 1.31 & 3.24 & 2.1 & 3.96 \\
\hline & FT4 [ng/dL] & $<0.40$ & 1.08 & 1.05 & 1.11 & 1.26 & 1.15 \\
\hline & FT3 $[\mathrm{pg} / \mathrm{mL}]$ & $<1.00$ & 3.11 & 3.69 & 4.06 & 3.76 & 4.14 \\
\hline \multirow{3}{*}{ IDS-P test } & $\begin{array}{l}\text { IO full-scale intelligence } \\
\text { quotient (IQ) }\end{array}$ & 89 & 104 & 113 & 109 & 110 & 132 \\
\hline & Fluid intelligence & 92 & 104 & 111 & 112 & 117 & 125 \\
\hline & Crystallised intelligence & 88 & 102 & 112 & 103 & 102 & 134 \\
\hline \multirow{7}{*}{ Cognitive skills } & Visual perception & 10 & 11 & 9 & 14 & 13 & 14 \\
\hline & Auditory memory & 3 & 9 & 14 & 11 & 12 & 15 \\
\hline & Selective attention & 9 & 11 & 11 & 13 & 13 & 13 \\
\hline & Phonological memory & 6 & 8 & 12 & 8 & 8 & 12 \\
\hline & Visual-spatial memory & 8 & 12 & 10 & 9 & 12 & 11 \\
\hline & Spatial reasoning & 13 & 13 & 13 & 13 & 13 & 14 \\
\hline & Conceptual reasoning & 14 & 10 & 11 & 13 & 14 & 13 \\
\hline \multirow{3}{*}{$\begin{array}{l}\text { Psychomotor } \\
\text { skills }\end{array}$} & Motorics & 9 & 11 & 9 & 15 & 15 & 11 \\
\hline & Manipulation & 12 & 12 & 13 & 14 & 14 & 13 \\
\hline & $\begin{array}{l}\text { Visual and auditory } \\
\text { co-ordination }\end{array}$ & 13 & 14 & 13 & 12 & 15 & 13 \\
\hline $\begin{array}{l}\text { Social } \\
\text { and emotional } \\
\text { competence }\end{array}$ & $\begin{array}{l}\text { Social and emotional } \\
\text { competence }\end{array}$ & 10 & 11 & 15 & 11 & 11 & 18 \\
\hline Mathematics & $\begin{array}{l}\text { Logical and } \\
\text { mathematical reasoning }\end{array}$ & 11 & 9 & 12 & 9 & 9 & 13 \\
\hline \multirow{3}{*}{ Language } & Active speech & 4 & 9 & 12 & 12 & 9 & 13 \\
\hline & Vocabulary & 8 & 12 & 13 & 10 & 12 & 12 \\
\hline & Passive speech & 4 & 14 & 11 & 14 & 14 & 14 \\
\hline \multirow{3}{*}{ Motivation } & Gratification delay & 13 & 13 & 12 & 11 & 13 & 12 \\
\hline & Persistence & 7 & 11 & 12 & 12 & 12 & 12 \\
\hline & $\begin{array}{l}\text { Achievement } \\
\text { satisfaction }\end{array}$ & 2 & 10 & 13 & 12 & 12 & 13 \\
\hline
\end{tabular}

Source: authors' data

The studied case seems interesting owing to the possibility of observing twin sisters and their development in the context of a disease that one of the girls was diagnosed with. Even more interestingly, the data indicate that the sister's improvement positively affected the healthy twin sister. The first evaluation pointed to the inharmonious development of specific cognitive functions in the hypothyroid girl. A detailed analysis of both strong and weak points of the observed girl revealed that low scores mainly involved speech development and language skills. Owing to the non-specific nature of difficulties demonstrated by the child, it is possible to conclude that the disease significantly affected the child's functioning and that the treatment she received stimulated her further development.

It has been proven in clinical studies that congenital hypothyroidism is the cause of intellectual impairment, which is most responsive to treatment and prevention [2]. The treatment was aimed at normal height and typical development of cognitive skills [3].

As a result of the analysis, the results were compared with normal distribution, and the profile of cognitive functions for both girls was developed. Also, for the hypothyroid sister, the dynamics of changes caused by received treatment were observed. It has been proven in clinical studies.

\section{References}

1. Fecenec D, Jaworowska A, Matczak A. IDS-P Skale Inteligencji i Rozwoju dla Dzieci w Wieku Przedszkolnym. Pracownia Testów Psychologicznych PTP, Warszawa 2013.

2. Foley TP. Hypothyroidism. Pediatr Rev. 2004; 25(3): 94-100, doi: 10.1542/pir.25-3-94, indexed in Pubmed: 14993517.

3. Raine JE, Donaldson MDC, Gregory JW. Thyroid disorders. In: Practical Endocrinology and Diabetes in Children. Blackwell, London 2006: 91-108. 